DOI 10.31558/2519-2949.2021.1.3

УДК 323.116:338.1:944.922(479.22)«20»

ORCID ID: https://orcid.org/0000-0003-0978-5417

Дунаєва Л. М., Одеський національний університет імені I.I. Мечникова

\title{
ПОЛІТИЧНА ТРАНСФОРМАЦІЯ ГРУЗЇ̈ У ПОСТБІПОЛЯРНИЙ ПЕРІОД
}

У статті досліджується прочес політичної трансформації Грузії з моменту проголошення ії незалежності. Гіпотеза полягає у тому, щзо політична трансформація Грузї̈ має привести до демократизачії ї̈ політичного режиму, що розглядається як прочес відходу від колишніх радянських практик функціонування політичної системи. Тож, політична трансформація $\epsilon$ багатовимірним процесом поступового відходу від соиіалізму. Авторка аналізує ряд чинників зміни політичних режимів, від першого демократичного уряду на чолі із Звіадом Гамсахурдією, з якого було розпочато прочес політичної трансформачії Грузії, приходом до влади Едуарда Шеварднадзе, i його усуненням в результаті масових протестів, які називають «кольоровою революиією» й які привели до перемоги на виборах Міхеіла Саакашвілі, політичну силу якого «Єдиний національний рух» було замінено «Грузинською мрією». Також, у досліджені вивчаються особливості політичного режиму Грузії, розглядається процес встановлення та розвитку владних відносин, визначено основні тенденції та зв'язки, які безпосередньо впливали на процес становлення політичної системи після здобуття незалежності у 1991 році. Метою дослідження є виявлення основних причин, які перешкоджали прочесу демократизачії Грузії, що сприяє розумінню закономірностей демократичного розвитку політичної системи країни. Основними методами $є$ емпіричний, проблемно-хронологічний, й метод кейс-стаді. У результаті дослідження було зроблено висновок, що політичній трансформащї Грузї притаманне поєднання авторитарних та демократичних тендениій. Трансформаційний процес крайни не був простим й однорідним, й започаткований прочес демократизаиії у Грузії є результатом розпаду радянської системи, який наразі можна охарактеризувати як незавершений перехід до консолідованої демократії. Проте, враховуючи прагнення Грузї стати членом НАТО та Свропейського Союзу, вирішення проблеми сецесіоністських регіонів на шляху розбудови демократичної держави є найважливішим.

Ключові слова: демократизачія, Грузія, політична трансформачія, демократія, політичний режим.

Постановка проблеми. Грузія була однією з держав колишнього Радянського Союзу, яка першою стала на шлях демократизації. Проте сучасна політична історія перетворилася на важке випробування для грузинської нації. Зіткнувшись з серйозними перешкодами у процесі розбудови демократичної політичної системи, пройшовши через жорстокі внутрішні конфлікти та військове зіткнення з Російською Федерацією у 2008 році, країні все ж таки вдалося провести радикальне реформування державного управління й стати на шлях європейської та євроатлантичної інтеграції. Внутрішньополітичний розвиток Грузії безпосередньо пов'язаний з безпекою всього Чорноморського регіону (не тільки Південного Кавказу), а й успіхом впливу країн Заходу на майбутнє моделі демократизації. У зв'язку з цим виникає необхідність аналізу процесу політичної трансформації та стану демократії в Грузії в період після розпаду Радянського Союзу до сьогодення. Це допоможе зрозуміти головні проблеми і перешкоди, які затримують процес іiі політичної трансформації на сучасному етапі.

Метою статті $є$ дослідити процес політичної трансформації Грузії з моменту досягнення нею незалежності. А також, виявлення основних причин, які перешкоджали процесу демократизації Грузії, що сприяє розумінню закономірностей демократичного розвитку політичної системи країни.

Аналіз останніх досліджень та публікацій. Особливості розвитку незалежної Грузії вивчала низка дослідників, зокрема питання процесу демократичного транзиту та розбудови демократичної політичної системи займає особливе місце в науковому доробку таких грузинських дослідників, як К. Гоголашвілі, В. Какачія, Г. Нодія, В. Долідзе, Д. Мікеладзе, Г. Мчедлішвілі, А. Кухіанідзе. Серед 
українських дослідників політичних процесів на Південному Кавказі та Чорноморському регіону слід виділити О. Брусиловську, С. Глебова, В. Дубовика, І. Максименко, Г. Шелест. Значний внесок у дослідження трансформації Південного Кавказу, й зокрема Грузії, належить таким аналітичним центрам, як Фонд імені Генріха Белля, Фонд Карнегі за міжнародний мир, Стокгольмський інститут дослідження проблем миру, та іншим західним неурядовим організаціям.

Виклад основного матеріалу дослідження. Розпад Радянського Союзу призвів до руйнації існуючих на той момент політичної та економічної систем, в умовах прогресуючої дестабілізації, націоналізму й міжетнічних протиріч з приводу майбутнього політичного устрою пострадянського простору. А припинення функціонування радянських державних інституцій та озброєні етнополітичні конфлікти вплинули на криміналізацію країни.

Політична незалежність Грузії розпочалася з проведення парламентських багатопартійних виборів у жовтні 1990 року, на яких перемогла опозиція «Круглий стіл - Вільна Грузія», очолювана іiі лідером - Звіадом Гамсахурдією, якого згодом було обрано головою грузинського парламенту. На референдумі про відновлення державної незалежності Грузії 31 березня 1991 року абсолютна більшість громадян $(98,9 \%)$ відповіла позитивно на поставлене питання, що означало фактичну незалежність Грузії [1, с. 252]. Після запровадження інституту президентства 3. Гамсахурдію було обрано президентом згідно рішенням Верховної Ради від 14 квітня 1991 року, та на всенародних виборах 26 травня 1991 року. 3 моменту свого призначення президент одразу зіткнувся з серйозними завданнями - Рачинськиим землетрусом, бойовими діями під Цхінвалі у Південній Осетії, невирішеним конфліктом в Абхазії тощо. Окрім того, Грузія разом з іншими пострадянськими країнами потерпала від соціально-економічної кризи.

Ряд зовнішньо та внутрішньополітичних прорахунків призвели до втрати влади першим президентом внаслідок військового перевороту. На початку 1992 року 3. Гамсахурдіа був змушений залишити столицю, й очолив уряд у вигнанні, згодом він загинув, переховуючись в гірській області Самегрело. У той час як в країні протягом 1992-1993 років розгорнулась справжня громадянська війна [1, с. 252].

На думку грузинських вчених-політологів перший президент Грузії був занадто зосереджений на національній міфології, це сприяло розповсюдженню місцевого націоналізму. Водночас, йому не вдалося знайти рішенням більш нагальним питанням, таким як економічна рецесія, суспільнополітична криза, військові конфлікти на території країни, криміналізація суспільства тощо [1, с. 252]. Проте основним його здобутком можна вважати декомунізацію грузинського суспільства та політичної системи [5, с. 887$]$.

Після того як влада в країні 2 січня 1992 року перейшла до рук тимчасового неконституційного органу «Військова Рада», було створено Державну Раду на чолі 3 колишнім першим секретарем ЦК Компартії Грузії Едуардом Шеварднадзе. Фактично відбувся військовий антиконституційний переворот. У жовтні 1992 року було проведено вибори до парламенту. Головою парламенту обрали Едуарда Шеварднадзе, що легітимізувало його керівництво країною [2, с. 96]. 3 цього моменту процес демократизації країни сповільнився, й почав набувати характеристик лібералізованого авторитаризму.

Після проведення президентських виборів у листопаді 1995 року, на яких перемогу отримав Едуард Шеварднадзе, набравши майже $73 \%$ голосів, ситуація в країні почала поступово стабілізуватися [2, с. 97]. 3 цього моменту починається період персоналізації влади, чому сприяли настрої населення щодо неможливості існування країни без «сильного» президента. Інститут президентства отримав повноваження визначального впливу на зовнішню політику, сферу національної безпеки та оборони, формування уряду та бюджету країни, та на законотворчий процес [2, с. 97].

Призначення на ключові урядові посади своїх колишніх колег - представників партійної радянської номенклатури призвело до реконсолідації радянського типу управління, при якому використовувалася демократична та націоналістична риторика, й впроваджувалися подвійні стандарти поведінки, що вплинуло вкрай негативно на демократичний процес [6, с. 148]. Таким чином, поступово консолідуючи власну владу, було послаблено демократичні інститути. Електоральні маніпуляції стали важливим механізмом консолідації режиму. Спроби опозиції прийняти поправки до виборчого законодавства, які б створювали більш конкурентні умови, не були вдалими. Едуарду Шеварднадзе вдалося де-факто очолювати уряд, незважаючи на повноваження парламенту щодо контролю над виконавчою владою, забезпечуючи своє домінування в політичній системі. Водночас законодавча влада фактично підпорядковувалася виконавчій, затверджуючи іiі ініціативи. Президентська партія «Союз громадян Грузії», що домінувала в парламенті, забезпечувала 
надійний контроль президента над парламентом [7, с. 121]

Таким чином, президенство Едуарда Шеварднадзе можна пов'язати з іншими режимами пострадянського простору, при яких особлива роль президентів, чиї повноваження часто виходять за формальні рамки, привертає багато уваги дослідників. Так, політолог Генрі Хейл для того щоб охарактеризувати подібні політичні системи ввів термін «патронального президенства». Патрональне президентство - це політичний інститут, а не окремий тип політичного режиму. Тому він існує в різних політичних умовах - при закритому авторитарному режимі, або у частково вільному політичному середовищі в Грузії. Система патронального президентства характеризується двома ключовими елементами. Перший елемент це президентська владою, яку президент отримує в результаті регулярних прямих виборів, на яких $\epsilon$ можливість проголосувати за альтернативного кандидата, та при цьому президентська влада домінує над іншими гілками влади за рахунок значних формальних повноважень у порівнянні з іншими гілками влади. По-друге, разом з великими формальними повноваженнями, президент має широкий набір неформальних повноважень, заснованих на відносинах «патрон-клієнт» на межі державної влади та економіки. Практично президент може вибірково спрямовувати значні матеріальні й владні ресурси, минаючи формальну інституційну систему. Важливо, що ці повноваження можуть бути використані не тільки для того, щоб досягати політичних цілей, але й для утримання влади президента шляхом нагородження союзників й усунення суперників [8, с. 137-139]. Саме в умовах патронального президенства, на думку Генрі Хейла, й відбуваються «кольорові» революції» [4, с. 12].

Це добре характеризує політичну ситуацію у Грузії напередодні виборів 2003 року. Окрім того, постійна економічна рецесія, зовнішній борг, що сягав майже двох мільярдів доларів США, соціальний песимізм, фальсифікації з боку влади на президентських й парламентських виборах, критика влади цивільним сектором численних великих корупційних скандалів привели до глибокої політичної кризи і зміни влади в результаті «Революції Троянд» листопада 2003 року [6, с. 149].

Внаслідок розгортання протестів Едуард Шеварднадзе подав у відставку 23 листопада 2003 року, й 4 січня 2004 року лідер опозиції Міхеіл Саакашвілі переміг, набравши 96\% голосів [2, с. 98]. Новий президент одразу розпочав проведення кардинальних ліберальних економічних реформ 3 метою послаблення контроля держави у процесі розвитку приватного бізнесу. 3 прийняттям у 2004 році нового податкового кодексу надходження до бюджету країни у 2007 році збільшилися у 2,7 рази $[1$, c. 253]. 3 метою додаткового захисту прав платників податків запроваджено посаду податкового омбудсмена, повністю звільнено від прибуткового податку власників мікробізнесу, та було полегшено податковий тиск на малий бізнес [1, с. 253].

Окрім того, Грузія розбудовувала відкриту економіку, тому фактично без обмежень виставила на продаж значну кількість державних компаній. Дрібні підприємства купували переважно місцеві компанії, а іноземні фірми купували великі об'єкти, що викликало бурхливе зростання іноземних інвестицій та ВВП країни [1, с. 254].

Таким чином, широкомасштабні реформи, різке зростання бюджетних надходжень дали змогу швидко відновити напівзруйновану інфраструктуру країни. Грузія досягнула значних успіхів в боротьбі 3 корупцією і контрабандою, й зборах податків. Позитивними стали макроекономічні показники. Окрім того, вдалося реінтегрувати автономну республіку Аджарія в економічну, соціальну й адміністративну систему Грузії, та відновити довіру до Грузії з боку іноземних донорів [6, с. 150].

Проте революційні методи реформування країни якісно не вплинули на покращення стану громадського сектору в країні. Країна все ще була на шляху до демократичної системи. У підсумку, на чергових парламентських виборах 2012 року, а потім і президентських виборах 2013 року, правляча партія «Єдиний Національний Рух» зазнала поразки, а до влади прийшла політична коаліція «Грузинська Мрія». На цьому етапі, величезним досягненням Грузії стало те, що вперше за пострадянський період, влада в країні змінилася в результаті вільних і справедливих виборів, а не в результаті державного перевороту або революції, що в 2012 році різко наблизило ії до країн 3 демократичним правлінням. На жаль, прихід нової політичної сили до влади демократичним шляхом не означав, що нова політична сила обов'язково завершить процес консолідації демократичного правління в країні. Період знаходження при владі «Грузинської мрії» можна охарактеризувати як неформальний та олігархічний, при якому всі три гілки влади, перебувають під контролем однієї політичної сили [6, с. 152].

Вчені зазначають, що нове керівництво Грузії, яким фактично керує Бідзіна Іванішвілі грузинський політик та підприємець, практично знищило всі досягнення колишньої влади, судова система в державі знову стала заангажованою та антидемократичною, на фоні чого відбувається 
поновлення корупційних скандалів та погіршення економічного стану країни [3, с. 64]. Загалом, ситуація для демократичних інституцій у Грузії є небезпечною, оскільки простір для діяльності політичних партій Грузії поступово зменшується, а корупція залишається широко розповсюдженою. Так, продовження демократичних перетворень в Грузії є малоймовірним [3, с. 66].

Однак, все ще однією з головних причин нестабільності політичної системи Грузії $€$ невирішеність територіального та міжнаціонального конфліктів. Ці конфлікти мають значний вплив на процес державного будівництва та на загальний розвиток країни. Етнічні меншини - абхази і осетини відчували себе об'єктом придушення, так як перші лідери незалежної Грузії вбачали в націоналізмі найбільш швидку й вигідну для себе форму мобілізації суспільства на свою підтримку. В результаті це вкрай негативно вплинуло на внутрішній і зовнішній розвиток країни. Окрім того, ще й створивши проблему у відносинах з Російською Федерацією, яка не сприймала Грузію як повністю незалежну й суверенну державу. Саме такий стан російсько-грузинських відносин створив для Грузії чи не один з головних викликів внутрішній і зовнішній безпеці. Все це неминуче призводило до недоліків в процесі демократизації та держбудівництва. Помилки в управлінні і пошуках вирішення цим проблемам приводили до політичного протистояння в країні, й змін режиму. Наслідки етнічних конфліктів відчуваються на політиці, економіці та суспільному добробуті Грузії, й стосуються безпеки регіону Південного Кавказу загалом. Результати конфлікту з Росією 2008 року були вкрай трагічними для Грузії. Визнання російською стороною незалежності Абхазії і Південної Осетії, що складають 20 \% території Грузії відклали проблему вирішення міжетнічного конфлікту в Грузії на невизначений термін, й привели до зростання військової присутності Росії в регіоні.

У 2010 році було ухвалено «Державну стратегію щодо окупованих територій: Залучення шляхом співпраці», яка мала на меті сприяти відновленню та поглибленню відносин між населенням Грузії, що виникли в результаті окупації, й забезпечити населенню Абхазії і Південної Осетії ті ж права і привілеї, якими користуються громадяни Грузії. На практиці це передбачало залучення Абхазії і Південної Осетії в міжнародні економічні взаємини Грузії, розвиток інфраструктури для вільного пересування населення і товарів, доступність грузинської системи охорони здоров'я для населення окупованих територій, й створення можливостей для населення цих територій отримати освіту в Грузії. Грузинський план мирної реінтеграції окупованих територій схвалив Захід, зокрема, Європейський Союз та НАТО, проте не підтримали російська сторона, Абхазія та Південна Осетія.

Обраний політико-дипломатичний шлях повернення окупованих територій поки що приніс країні тільки схвалення з боку західних партнерів. Це позитивно вплинуло на підписання Грузією Угоду про асоціацію з СС, та отримання режиму вільної торгівлі та візової лібералізації, що $\epsilon$ значними кроками на шляху євроінтеграції. Проте окуповані автономії все ще залишаються територіями, неконтрольованими центральною владою, де активно поширюється російський вплив. Таким чином, оскільки позитивного рішення абхазької і осетинської проблемам ще не вдалося досягнути це означає, що Грузія з високим ступенем вірогідності й надалі зустрічатиме перешкоди на шляху своєї політичної трансформації. Вирішення цих проблем є нагальним для встановлення демократичного режиму у країні.

Аналізуючи досвід Грузії в побудові незалежної демократичної держави варто зазначити наступне. Перехід до демократії не є лінійним процесом і не завжди призводить до встановлення стабільного демократичного режиму, що демонструє нам процес політичної трансформації Грузії. Держава, яка стає на шлях демократичного розвитку завжди проходить через період певної нестабільності, й ризикує перетворитися у авторитарну, й у більшості випадків проходить через труднощі економічного спаду. Політична трансформація Грузії є недосконалою, не дивлячись на те, що певний проміжок часу вона була головним прикладом демократизації на пострадянському просторі. Наразі трансформаційний процес країни важко однозначно охарактеризувати. Нагальним $є$ вирішення територіальних та міжнаціональних питань для попередження антидемократичних тенденцій розвитку політичної системи країни. Проте, Грузії за час іiі незалежного існування все ж таки вдалося здійснити перехід від авторитаризму до розбудови демократії, нехай і неконсолідованої.

\section{Бібліографічний список:}

1. Особливості суспільно-політичної модернізації країн пострадянського простору: монографія / ред. А. Г. Бульвінського. Київ : Ін-т всесвіт. історії НАН України, 2017. 288 с.

2. Паска О. Становлення та розвиток інституту президентства у посткомуністичній Грузії. Ефективність державного управління. 2016. № 3. C. 95 - 101. URL: http://nbuv.gov.ua/UJRN/efdu_2016_3_11.

3. «Суспільний ідеал» $\mathrm{i}$ «політичний інтерес»: теоретичне осмислення і практика країн світу / кер. авт. колективу А. Кудряченко. Київ: Держ. установа «Ін-т всесвіт. історії НАН України, 2019. 77 с. 
4. Хейл Г. Президентський режим, революція і демократія. Pro et Contra. 2008. № 1. С. 6 - 21.

5. Долидзе В. М. Посткоммунистическая трансформация и циклы политического развития Грузии. Постсоветские исследования. 2019. № 1. С. 885 - 892 .

6. Кухианидзе А. Демократия и политическая трансформация в Грузии (1991-2018). Bосток Eвропы. 2018. № 2. C. 137 - 155. URL: https://doi.org/10.17951/we.2018.4.2.137.

7. Прокофьев А. В. Институциональные факторы трансформации политических режимов Грузии, Киргизии и Украины (начало 2000-х годов). Политическая экспертиза: ПОЛИТЭКС. 2010. № 2. С. 116 - 132.

8. Hale H. Regime Cycles. Democracy, Autocracy, and Revolution in Post-Soviet Eurasia. World Politics. 2005. No. 10. P. $137-139$.

\section{References:}

1. Osoblivosti suspilno-poitichnoyi modernizatsiyi krayin postradyanskogo prostoru: monograftya / red. A. G. Bulvinskogo. Kyiv: In-t vsesvit. Istoriyi NAN Ukrayini, 2017. 288 s.

2. Paska O. Stanovlennya ta rozvitok institutu prezidentstva u postkomunistichniy Gruziyi. Efektivnist derzhavnogo upravilnnya. 2016. № 3. S. 95 - 101. URL: http://nbuv.gov.ua/UJRN/efdu_2016_3_11.

3. «Suspilniy ideal» $\mathrm{i}$ «politichniy interes»: teoretichne osmislennya i praktika krayin svitu / ker. avt. kolektivu A. Kudryachenko. Kyiv: Derzh. ustanova «In-t vsesvit. Istoriyi NAN Ukrayini, 2019. 77 s.

4. Heyl G. Prezidentskiy rezhim, revolyutsiya i demokratiya. Pro et Contra. 2008. № 1. S. 6 - 21.

5. Dolidze V. M. Postkommunisticheskaya transformatsiya i tsiklyi politicheskogo razvitiya Gruzii. Postsovetskie issledovaniya. 2019. № 1. S. $885-892$.

6. Kuhianidze A. Demokratiya i politicheskaya transformatsiya v Gruzii (1991-2018). Vostok Evropyi. 2018. № 2. S. 137 - 155. URL: https://doi.org/10.17951/we.2018.4.2.137.

7. Prokofev A. V. Institutsionalnyie faktoryi transformatsii politicheskih rezhimov Gruzii, Kirgizii i Ukrainyi (nachalo 2000-h godov). Politicheskaya ekspertiza: POLITEKS. 2010. № 2. S. 116 - 132.

8. Hale H. Regime Cycles. Democracy, Autocracy, and Revolution in Post-Soviet Eurasia. World Politics. 2005. No. 10. P. $133-165$.

\section{Dunaeva L. M. Political Transformation of Georgia During Post-bipolar Period}

The article studies the process of political transformation of Georgia since the declaration of its independence. The author's hypothesis is that Georgia's political transformation should lead to the democratization of its political regime, which in this study is seen as a process of departure from the former Soviet practices of the political system. That is, political transformation is a multidimensional process of gradual departure from socialism. The author analyses a number of factors of the political regime change, from the first democratic government of Zviad Gamsakhurdia, which began the process of political transformation of Georgia, the coming to power of Eduard Shevardnadze, and his resignation in a result of mass protests called "colour revolution", leading to the election victory of Mikheil Saakashvili, whose political force, the United National Movement, was replaced by the Georgian Dream. Also, the study examines the features of the political regime in Georgia, examines the process of establishment and development of power relations, and identifies the main trends and links that directly influenced the process of development of the political system since 1991. The aim of the study is to identify the main reasons that hindered the process of democratization of Georgia, contributing to the understanding of the patterns of democratic development of the country's political system. The main methods used are empirical, problemchronological, and case study method. The author concludes that Georgia's political transformation can be characterized by a combination of authoritarian and democratic tendencies. The country's transformation process has not been simple and homogeneous, and the on-going process of democratization in Georgia is the result of the collapse of the Soviet system, which can now be described as an incomplete transition to a consolidated democracy. However, given Georgia's aspirations to become a member of NATO and the European Union, resolving the problem of secessionist regions on the path to building a democratic state is extremely important.

Keywords: democratization, Georgia, political transformation, democracy, political regime. 